Int. J. Morphol.,

34(3):1039-1043, 2016.

\title{
Report on a Sheet Plastination Technique using Commercial Epoxy Resin
}

\author{
Reporte Sobre una Técnica de Plastinación de Cortes Usando una Resina Epoxy Comercial
}

\author{
Nicolás Ernesto Ottone ${ }^{*, * *}$; Mariano del Sol ${ }^{* *, * *,, * * * * * *}$ \& Ramón Fuentes ${ }^{*}$
}

OTTONE, N. E.; DEL SOL M. \& FUENTES, R. Report on a sheet plastination technique using commercial epoxy resin. Int. J. Morphol., 34(3):1039-1043, 2016.

SUMMARY: Plastination is a conservation technique which allows anatomical pieces to be preserved, dry and odor-free, for an indefinite period. In particular, plastination of sections of tissue with epoxy resin allows very thin slices to be made of various regions of the anatomy, permitting close viewing of anatomical structures which are difficult to access by dissection or cadaver exploration. The objective of this work is to present a plastination technique developed in our laboratory for tissue sections using commercial epoxy resin, as an alternative to the existing classic plastination techniques. The technique was applied to a human knee, obtaining $5 \mathrm{~mm}$ thick sections which were compared with computerized tomography images. The development of an alternative sheet plastination technique using epoxy resin allows the preservation of anatomical regions which are difficult to study, with the possibility of comparing the sections with imaging studies. In this way anatomy can be usefully combined with clinical experience, allowing students to gain more significant knowledge of anatomy. The technique would also ensure provision of anatomical samples for research in the area of morphological science.

KEY WORDS: Sheet plastination; Epoxy resin.

\section{INTRODUCTION}

The development of anatomical techniques for fixing and preserving cadavers was advanced by the appearance of the plastination technique, created by Prof. Gunther von Hagens in 1977 in Heidelberg, Germany, and subsequently diversified and developed by various research centers in recent years (Fasel et al., 1988; Weber \& Henry, 1993; Cook \& Al-Ali, 1997; Steinke, 2001; Shahar et al., 2007; Sora et al., 2003; Sora \& Cook, 2007; Al-Ali et al., 2009; Soal et al., 2010; Scali et al., 2015). The objective of the technique is to obtain dry preparations with some degree of rigidity and/or flexibility and which can be kept for long periods. It involves a series of steps: First dehydration of the preparation, then incorporation of silicon to replace the acetone by forced impregnation, and finally curing of the specimen to allow final polymerization. The technique became publicly known through von Hagens' exhibitions and samples "Bodyworlds", but development had already started in various universities for anatomy teaching. Its application is also gradually being incorporated into morphological research. One of the most important applications of plastination in this research field is for preserving tissue sections. The aim of the present work is to present an alternative sheet plastination technique, developed in the Plastination Laboratory of the Dental School of Universidad de La Frontera, Chile. This technique allows the preservation of plastinated anatomical sections not only to improve student learning, but also to carry out morphological research with applications in clinical practice and surgery.

\section{MATERIAL AND METHOD}

Plastination was applied to sections of a human knee and upper portion of the leg, from an adult male fixed and preserved in buffered formalin at $5 \%$. Before plastination was carried out, the knee was studied by computed tomography $(\mathrm{CT})$ imaging in a Toshiba multi-slice helical

Laboratory of Plastination and Anatomical Techniques, Research Centre in Dental Sciences (CICO), Dental School, Universidad de La Frontera, Temuco, Chile.

** Doctoral Program in Morphological Sciences, Medicine School, Universidad de La Frontera, Temuco, Chile.

**** Center of Excellence in Morphological and Surgical Sciences (CEMyQ), Universidad de La Frontera, Temuco, Chile.

**** Center of Biomedical Sciences Research, Universidad Autónoma de Chile, Temuco, Chile. 
tomography machine with 16 detectors. In Table I was shown the steps of the technique.

The technique developed in our laboratory is described below:

A. Preparation of the block for sectioning. To section the sample more easily it is placed in a container (wood or cardboard) and covered with polyurethane foam, which hardens in 24 hours. The whole block, consisting of the container with the polyurethane-surrounded sample, is placed in a freezer at $-25^{\circ} \mathrm{C}$ to $-20^{\circ} \mathrm{C}$ for at least 2 weeks.

B. Sectioning the sample. The polyurethane block containing the sample is taken out of the box for sectioning and placed on the cutting table. This should have a cutting guide which allows the thickness of the section to be measured. The cutting machine should have a thin saw blade with fine teeth, to allow cuts to be made with minimum loss of material. The objective is to cut sections of $5 \mathrm{~mm}$ thickness or less. Once the sections have been cut they are dehydrated.

C. Dehydration. To dehydrate the sections they are passed through two consecutive acetone baths, the first at purity greater than $90 \%$ and the second at $100 \%$. Both baths may be of acetone at $100 \%$. The density of the acetone must be checked throughout the dehydration process, which takes approximately 6 to 8 days, with approximately 3 to 4 days in each bath. We recommend carrying out dehydration at a temperature of $-25^{\circ} \mathrm{C}$ to $-20^{\circ} \mathrm{C}$. Once dehydration is complete, a further 4 days are required to eliminate the fat from the sections, in a bath of either acetone at $100 \%$ or methylene chloride.

D. Forced impregnation (Table II). Forced impregnation is carried out over two days, with active and passive stages (Ottone et al., 2014; 2015). First the samples are placed in epoxy resin (without the catalyst, because of the type of epoxy resin, previously accelerated) and left for 2 hours without activating the vacuum pump ("passive forced impregnation"). The vacuum pump is then activated to start the "active forced impregnation" stage. In this stage the acetone will be extracted as the resin is incorporated into the samples, evidenced by bubbles rising to the surface. During the first day the pressure can be taken from 760 $\mathrm{mmHg}$ to $50 \mathrm{mmHg}$, over a total period of 10 hours. Once a pressure of $50 \mathrm{mmHg}$ is reached, after 10 hours continuous work by the vacuum pump, the pump is switched off without breaking the vacuum in the chamber, which must remain closed to maintain the pressure until the next day. Switching off the pump starts a new period of "passive forced impregnation", allowing equilibrium to be established between the entry of resin and the exit of silicone, such that the polymer is incorporated smoothly, avoiding excessive retraction of the tissue. This passive period is maintained for 10 hours. On completion the vacuum pump is switched on again, and a new period of "active forced impregnation" begins, the main aim of which is to reduce the pressure from $50 \mathrm{mmHg}$ to the final pressure of $5 \mathrm{mmHg}$. This is also done over a period of 10 hours and requires gradual, gentle, continuous reduction in the pressure. Combined with the previous periods of "passive forced impregnation" this will lead to correct introduction of the resin into the sample, and most importantly a drastic reduction in the possibility of tissue retraction. Once the pressure of $5 \mathrm{mmHg}$ is reached and no more bubbles are observed, forced impregnation is complete and the next stage can begin.

Throughout this process the temperature inside the vacuum chamber must be monitored strictly with a thermometer, since the epoxy resin starts to harden when the temperature rises above $30^{\circ} \mathrm{C}$. We experienced no temperature problems during active and passive forced impregnation; the temperature never reached $30^{\circ} \mathrm{C}$.

E. Curing. Immediately the forced impregnation process is complete, the samples are taken out of the resin and the curing chambers are set up. These are flat or "sandwich" chambers in which the samples are cured by polymerization.

The following materials are required for the curing chambers: rectangular plates of glass 2 to $3 \mathrm{~mm}$ thick (the size of the plates will depend on the size of the samples to be cured), sheets of acetate (of the same size as the glass plates) and binder clips.

Place one sheet of acetate on one of the glass plates, then pour a limited amount of epoxy resin-catalyst mixture (50:50, by producer recommendation) onto the acetate. Place the tissue sections on the mixture, with at least $15 \mathrm{~mm}$ between them. Subsequently, pour a further amount of epoxy resin-catalyst mixture (50:50) over the sample. Place a second sheet of acetate on the sections, followed by the second glass plate. Press the glass plates together to ensure even distribution of the resin between the sections, and that they are all completely covered. Then fix the glass plates by placing binder clips round the sides.

The completed curing chamber should be done at room temperature for $24 \mathrm{hs}$. At the end, the chamber can be dismantled, removing the clips and glass plates to leave the sections between the sheets of acetate. These can then be peeled off to leave the hard, dry sections embedded in resin. If necessary the excess resin can be removed by cutting round the sections with scissors. 
Table I. Steps of the technique.

Day 1: Cut specimen.

Day 2: Dehydration, 1 st acetone bath at $-25^{\circ} \mathrm{C}(>90 \%)$.

Day 5: Dehydration, 2nd acetone bath at $-25^{\circ} \mathrm{C}(100 \%)$. Check purity / density $1^{\text {st }}$ bath.

Day 8: Dehydration, 3rd acetone bath at $-25^{\circ} \mathrm{C}(100 \%)$. Check purity / density $2 \mathrm{n}^{\mathrm{d}}$ bath.

Day 11: Degrease cuts with acetone or methylene chloride at room temperature.

Day 18: Forced Impregnation (32 hours):

- 1 day: $760 \mathrm{mmHg}$ to $50 \mathrm{mmHg}$.

- 2nd day: $50 \mathrm{mmHg}$ to $5 \mathrm{mmHg}$.

Day 20: Curing, 2 possible methods: "flat chamber" or "sandwich".

Day 21: Place in an oven at $45^{\circ} \mathrm{C}$ for 4 days.

Day 25: Open "flat chamber" or "sandwich", cover with plastic wrap.

Table II. Forced impregnation process. In a two-day technique, the periods of active forced impregnation ( $10 \mathrm{~h}$ each) and passive forced impregnation are combined ( 2 and 10 hours depending on the day). The point here is to bring the pressure inside the vacuum chamber of $760 \mathrm{mmHg}$ to $5 \mathrm{mmHg}$, and at this final pressure, when the bubbles disappear, the forced impregnation process is over.

\begin{tabular}{lll}
\hline Days & Forced Impregnation & Pressure \\
\hline 1 st & "Passive" (2 hours) & $760 \mathrm{mmHg}$ \\
& "Active" (10 hours) & 760 to $50 \mathrm{mmHg}$ \\
$1 \mathrm{st} / 2^{\text {nd }}$ & "Passive" (10 hours) & $50 \mathrm{mmHg}$ \\
$2 \mathrm{n}^{\mathrm{d}}$ & "Active" (10 hours) & $50 \mathrm{mmHg}$ to $5 \mathrm{mmHg}$ \\
\hline
\end{tabular}

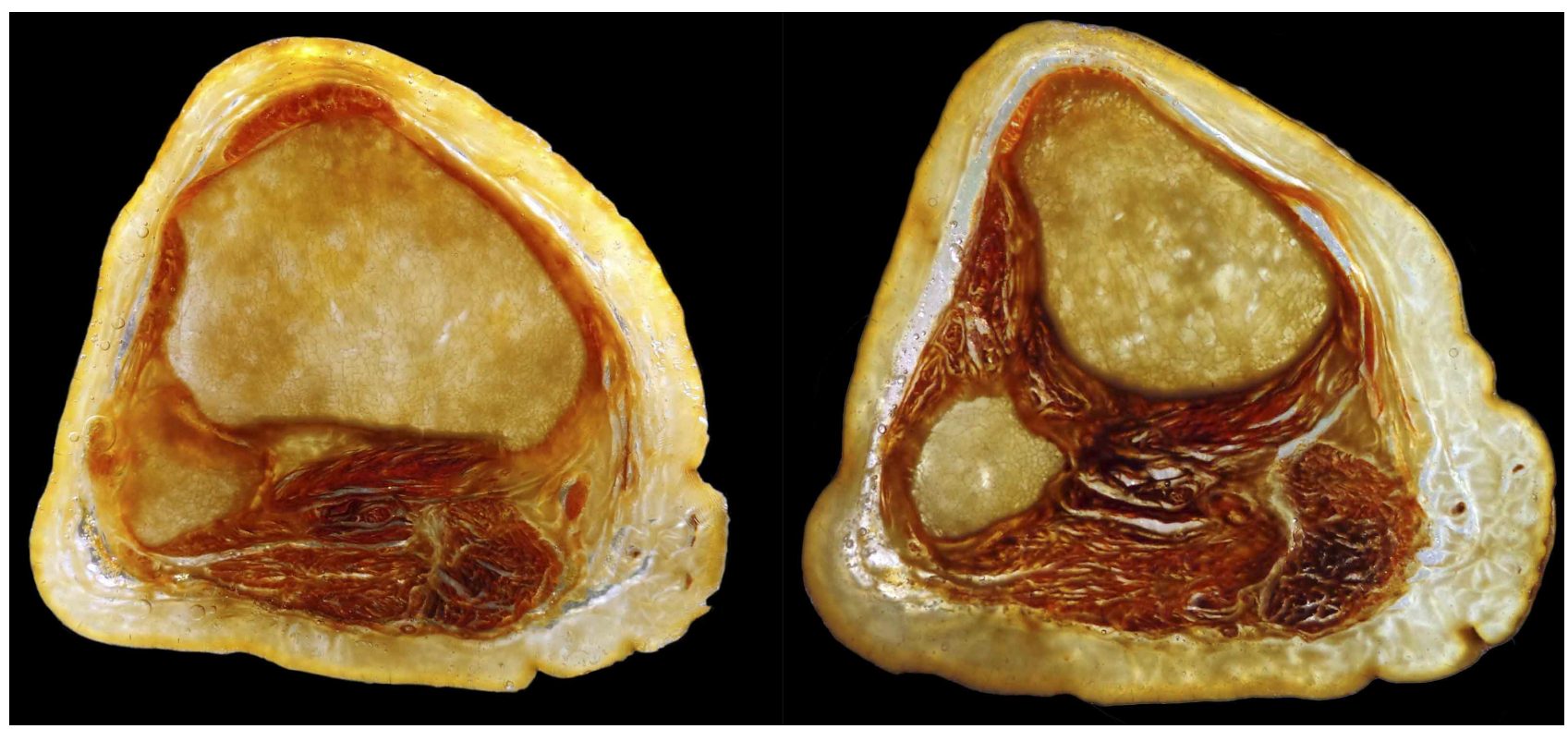

Fig. 1. Horizontal sections of the upper portion of the leg. 


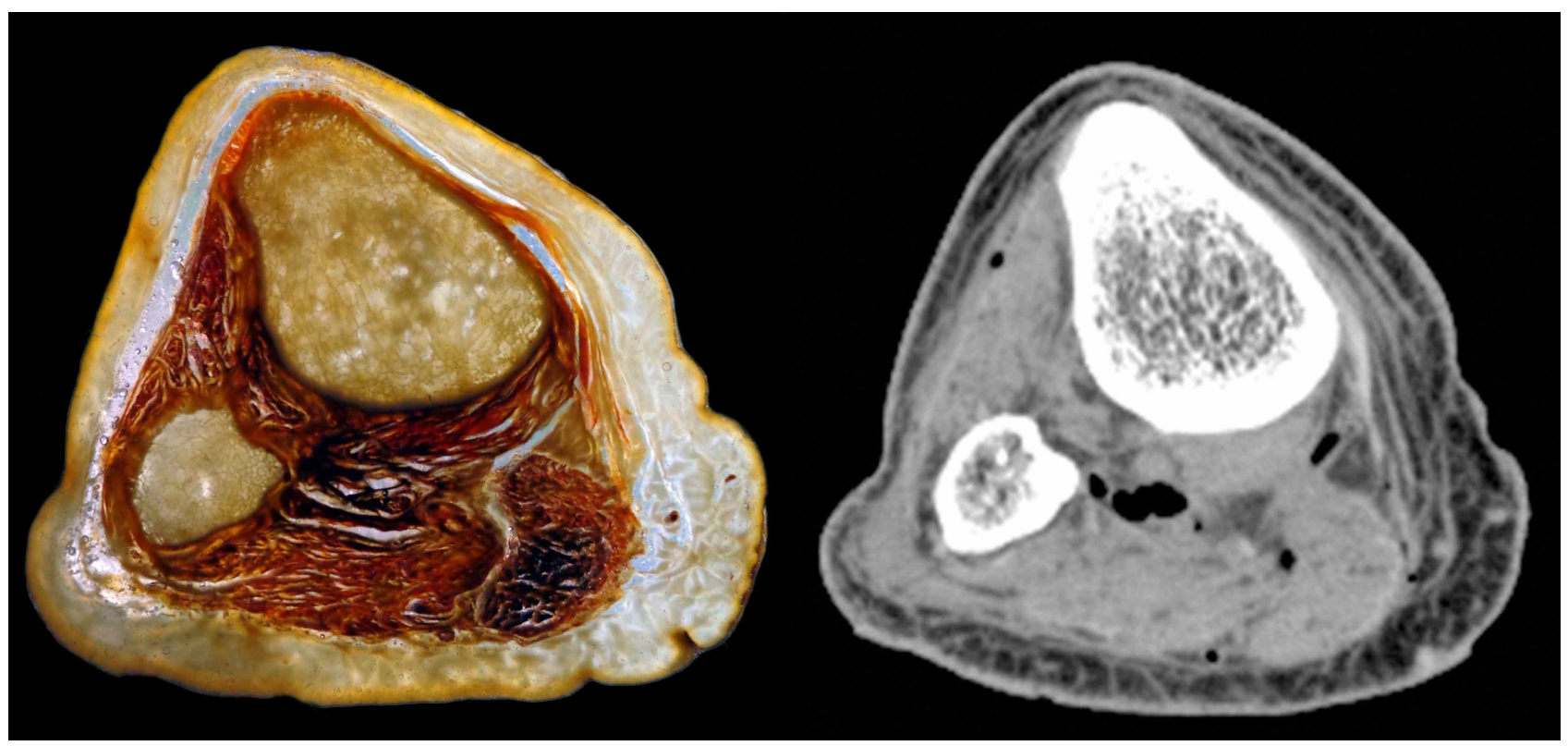

Fig. 2. Comparison of the plastinated specimen with the CT image of the specimen, prior to the plastination technique.

\section{DISCUSSION}

The basic advantage of the sheet plastination technique, in this case using epoxy resin, is that it allows the complete topographical arrangement of anatomical structures to be preserved, showing their morphological characteristics and the relation between them (Sora \& Cook).

It has been shown that plastinated sections can be compared with imaging studies. Plastinated sections offer the advantage over anatomical sections preserved in other types of fixing liquid (e.g. formalin) that very thin sections can be cut; furthermore they offer a precise view of the different anatomical structures in the section and how they relate to one another anatomically. Although thin sections can be obtained with other types of fixer or by freezing, subsequent indefinite preservation with no toxicity is another advantage offered by plastination. This technique also improves understanding of the images obtained by radiological techniques (either CT or MR), allowing better interpretation of imaging studies.

The sections can be stored at room temperature and used subsequently for research purposes. Morphological measurements can be taken easily. The data obtained were compared with high definition magnetic resonance images (Cook \& Al-Ali; Steinke; Al-Ali et al.). According to Sora $\&$ Cook, the only disadvantage found is that epoxy resin sections tend to turn yellow over a period of several years.
Removing the lipid content from the tissue sections before impregnation is an essential step for success with the epoxy resin technique. Acetone, the recommended medium for cold dehydration, is also a good fat-removing solvent when used at ambient temperature. The best optical quality in sections plastinated in epoxy resin, was achieved when the fat was removed from the tissue by first treating with acetone at ambient temperature and then transferring to methylene chloride to extract further lipids (Shahar et al., 2007; Sora \& Cook, 2007).

For research purposes, these sections allow topographic study of all the body's structures with no problems caused by collapse or dislocation. The samples are also useful in training programs for residents in advanced studies of topographic sections, and in CT and MR training. Computerised reconstruction of anatomical structures from plastinated specimens are very useful for learning about anatomy, for research and for creating animations in teaching modules.

OTTONE, N. E.; DEL SOL M. \& FUENTES, R. Reporte sobre una técnica de plastinación de cortes usando una resina epoxy comercial. Int. J. Morphol., 34(3):1039-1043, 2016.

RESUMEN: La plastinación es una técnica anatómica de conservación cadavérica que permite la preservación por tiempo 
indeterminado, en forma seca y sin olor, de piezas anatómicas. En particular, la técnica de plastinación por cortes, con resina epoxy, permite a su vez la generación de cortes delgados de diversas regiones anatómicas, permitiendo una visualización precisa de estructuras anatómicas de difícil acceso a través de la disección o la exploración cadavérica. El objetivo de este trabajo es el de presentar el desarrollo por parte de nuestro laboratorio de una técnica de plastinación de cortes con resina epoxy comercial, alternativa a las técnicas clásicas de plastinación de cortes existentes. Se aplicó la técnica en una rodilla humana, obteniéndose cortes de $5 \mathrm{~mm}$ de espesor, los cuales fueron comparados con imágenes de tomografía computada. El desarrollo de una técnica alternativa de plastinación de cortes con resina epoxy permitirá la conservación de regiones anatómicas de difícil estudio, con posibilidad de realizar la comparación de cortes con estudios imagenológicos, para combinar en forma adecuada la anatomía con la experiencia clínica y, de esta manera, permitir que el alumno alcance un aprendizaje más significativo de la anatomía, además de asegurar la obtención de muestras anatómicas para el desarrollo de investigación en el área de las ciencias morfológicas.

PALABRAS CLAVE: Plastinación de cortes; Resina

epoxy.

\section{REFERENCES}

Al-Ali, S.; Blyth, P.; Beatty, S.; Duang, A.; Parry, B. \& Bissett, I. P. Correlation between gross anatomical topography, sectional sheet plastination, microscopic anatomy and endoanal sonography of the anal sphincter complex in human males. $J$. Anat., 215(2):212-20, 2009.

Cook, P. \& Al-Ali, S. Submacroscopic interpretation of human sectional anatomy using plastinated E12 Sections. J. Int. Soc. Plast., 12(2):17-27, 1997.

Fasel, J.; Mohler, R. \& Lehmann, B. A technical note for improvement of the E12 technique. J. Int. Soc. Plast., 2(1):47, 1988.

Ottone, N. E.; Cirigliano, V.; Lewicki, M., Bianchi, H. F.; AjaGuardiola, S.; Algieri, R. D.; Cantín, M. \& Fuentes, R. Plastination Technique in Laboratory Rats: an Alternative Resource for Teaching, Surgical Training and Research Development. Int. J. Morphol., 32(4):1430-5, 2014.

Ottone, N. E.; Cirigliano, V.; Bianchi, H. F.; Medan, C. D.; Algieri, R. D.; Borges Brum, G. \& Fuentes, R. New contributions to the development of a plastination technique at room temperature with silicone. Anat. Sci. Int., 90(2):126-35, 2015.

Scali, F.; Nash, L. G. \& Pontell, M. E. Defining the morphology and distribution of the alar fascia: A sheet plastination investigation. Ann. Otol. Rhinol. Laryngol., 124(10):814-9, 2015.
Shahar, T.; Pace, C. \& Henry, R. W. Epoxy plastination of biological tissue: VisDocta EP73 technique. J. Int. Soc. Plast., 22:46-9, 2007.

Soal, S.; Pollard, M.; Burland, G.; Lissaman, R.; Wafer, M. \& Stringer, M. D. Rapid ultrathin slice plastination of embalmed specimens with minimal tissue loss. Clin. Anat., 23(5):53944, 2010.

Sora, M. C.; Strobl, B. \& Radu, J. High temperature E12 plastination to procedure ultra-thin sheets. J. Int. Soc. Plast., 19:22-5, 2003.

Sora, M. C. \& Cook, P. Epoxy plastination of biological tissue: E12 technique. J. Int. Soc. Plast., 22:31-9, 2007.

Steinke, H.; Pfeiffer, S. \& Spanel-Borowski, K. A new plastination technique for head slices containing brain. Ann. Anat., 184(4):353-8, 2001.

Weber, W. \& Henry, R. W. Sheet plastination of body slices - E12 technique, filling method. J. Int. Soc. Plast., 7:16-2, 1993.

\author{
Dirección de Correspondencia: \\ Nicolás Ernesto Ottone \\ Laboratory of Plastination and Anatomical Techniques \\ Research Centre in Dental Sciences (CICO) \\ Dental School \\ Universidad de La Frontera \\ Temuco \\ CHILE.
}

E-mail: nicolas.ottone@ufrontera.cl

Recibido : 16-05-2016

Aceptado: 02-07-2016 